\title{
A rapid method to assess the aggressiveness of Eutypa lata isolates and the susceptibility of grapevine cultivars to Eutypa dieback
}

\author{
JP Péros*, G Berger \\ INRA, station de recherches viticoles, centre de Montpellier, BP 13, F34751 Villeneuve-les-Maguelone cedex, France
}

(Received 20 October 1993; accepted 27 October 1994)

\begin{abstract}
Summary - A method was developed to study the grapevine dieback caused by Eutypa lata in the greenhouse. Plugs of mycelium and PDA medium were inserted into holes made $4 \mathrm{~cm}$ below the buds of unrooted cuttings. Shoots arising from inoculated cuttings exhibited typical foliar symptoms of Eutypa dieback as early as the $F$ stage. Different isolates of $E$ lata displayed considerable variation in the incidence of symptoms. All the isolates could colonize the cuttings but some of them did not induce foliar symptoms. All the inoculated cultivars presented the symptoms of the disease and varied in resistance.
\end{abstract}

grapevine / Eutypa dieback / inoculation method / pathogen variability / cultivar susceptibility

Résumé - Une méthode rapide pour évaluer l'agressivité des isolats d'Eutypa lata et la sensibilité des cépages de vigne à l'eutypiose. Une méthode a été mise au point en serre pour étudier le dépérissement de la vigne dû à Eutypa lata. Des cylindres de mycélium et de milieu PDA ont été placés dans des trous percés $4 \mathrm{~cm}$ au-dessous des bourgeons de boutures non racinées. Les pousses montrent les symptômes foliaires caractéristiques de la maladie dès le stade $F$. La sévérité des symptômes dépend de l'isolat d'E lata utilisé. Tous les isolats se sont révélés capables de coloniser les boutures mais certains n'ont pas induit de symptômes foliaires. Tous les cépages ont montré les symptômes de la maladie et différents niveaux de sensibilité ont été mis en évidence.

vigne / eutypiose / méthode d'inoculation / variabilité du parasite / sensibilité variétale

\section{INTRODUCTION}

The fungus Eutypa lata (Pers:Fr) Tul ( = E armeniacae Hansf and Carter) is a major cause of grapevine (Vitis vinifera $L$ and interspecific hybrids) and apricot (Prunus armeniacae L) declines throughout the world (Carter, 1991). Infection of a vine is initiated when ascospores of the fungus enter wounds, especially after pruning, and then the mycelium colonizes the wood. Cross-sections of arms and trunks of diseased vines show wedge-shaped zones of necrotic sapwood. The external symptoms of Eutypa dieback

* Correspondence and reprints 
are most conspicuous during the first months of the annual growth cycle and include dwarfed shoots with smaller and necrotic leaves (Bolay and Moller, 1977).

Studies of the disease are complicated by the length of time between infection and the appearance of the first symptoms, which may be several years in the vineyard. The need for rapid methods is thus of prime importance. A good knowledge of the host-parasite relationships is necessary to develop such methods, and serious gaps existed in the comprehension of the Eutypa dieback. Moller and Kasimatis (1981) suggested that the fungus acts through toxins because shoot symptoms appear at distance of colonized wood parts. A toxin, named eutypine, was effectively detected in liquid cultures of $E$ lata (Renaud, 1985) and diseased plants (Tey-Ruhl et al, 1991). In vitro-grown materials have been placed in contact with mycelium (Belarbi, 1983; Mauro et al, 1988), culture filtrate (Mauro et al, 1988) and eutypine (Fallot et al, 1990; Soulié et al, 1993). The biossays demonstrated some variation in the fungus and in the grapevine host. Another important component of the pathogenesis appears to be the fungal ability for wood colonization. Methods to quantify lignin degradation capacity (Elghazali et al, 1992) and different enzymatic activities (Chapuis, personal communication) have been used to compare isolates of E lata.

Laboratory tests are carried out in far from natural conditions and probably cannot take into account all the components of pathogenesis. Therefore, development of methods intermediate between field trials and laboratory tests may be of great interest. Petzoldt et al (1981) reported that isolation from rooted-cuttings of first-year canes inoculated with ascospores can provide rapid results. In addition, they observed that some of the inoculated plants showed leaf symptoms during the second vegetative growth cycle. A higher incidence of foliar symptoms was obtained by Mur (1988) who inoculated unrooted cuttings with mycelium using 2 different methods. In one, inoculum was introduced into a hole drilled mainly in the pith at the cutting base. In the other, the inoculum was inserted at the graft junction of self-grafted cuttings. However, symptoms were again observed during the second vegetative growth cycle.

In this study we present evidence that inoculation of cuttings can induce leaf symptoms during the first vegetative growth cycle of different grape cultivars. The method appears suitable to demonstrate differences in agressiveness among isolates of $E$ lata as well as differences in response among vine cultivars.

\section{MATERIALS AND METHODS}

\section{Origin of isolates}

Isolates were obtained from single ascospores or from mycelia cultured from necrotic wood. For single spore isolation, perithecia were placed in water, ascospore suspensions were then diluted and streaked in plates onto potato-dextrose agar (PDA, Difco Laboratories). After a $24 \mathrm{~h}$ incubation at $25^{\circ} \mathrm{C}$, small cubes of medium with single germinated ascospores were transferred onto PDA plates. For mycelium isolation from wood, thin cross-sections were made with a saw and pieces of wood $(10 \times 5 \times 5 \mathrm{~mm})$ were cut with pruning shears at the necrotic margin. Wood pieces were surface disinfected for $15 \mathrm{~min}$ in calcium hypochlorite at $2.5 \%$ active chlorine and rinsed in 3 changes of sterile water. Several chips were then cut aseptically from each piece and placed onto PDA plates. After incubation for $5-8 d$ at $25^{\circ} \mathrm{C}$, the mycelium that originated from the ascospores or wood chips was subcultured once to check purity. Discs (5 $\mathrm{mm}$ diameter) from these cultures were placed in $2 \mathrm{ml}$ tubes containing $1 \mathrm{ml}$ of sterile distilled water and stored at $4^{\circ} \mathrm{C}$.

The isolates originated from France, Australia, Greece and Switzerland (table I). Eight isolates derived from single ascospores. AD30 and MA26 isolates were obtained from the Federal Agricultural Research Station, Changins, Switzerland, collection numbers 889 and 300; both originated from an apricot host. The other isolates were obtained from grapevines in our laboratory in 1990-1991.

\section{Inoculation of cuttings}

Branches were collected in November-December and stored at $4^{\circ} \mathrm{C}$. The day before the inoculation, 2-node cuttings with the basal bud eliminated were prepared and soaked in water overnight. A hole $(5 \mathrm{~mm}$ diameter, $5 \mathrm{~mm}$ deep) was drilled $4 \mathrm{~cm}$ below the upper bud and a plug (5 mm diameter) of agar and mycelium, cut from a fresh culture on PDA medium $\left(10-15 \mathrm{~d}\right.$ at $25^{\circ} \mathrm{C}$ ), was inserted into the hole with the mycelium towards the wood. The inoculation site was covered with a plastic film. For the control, plugs of PDA medium were used. The cuttings were not disinfected before inoculation.

The effect of the position of the inoculation site was studied. Cuttings of cv Cabernet Sauvignon (clone 191) from a breeding plot of the station were inoculated in June 1990 with isolate BX1-10. The inoculum was placed $4 \mathrm{~cm}$ either under the bud or on the opposite side. 
Table I. Identification and sources of the isolates of $E$ lata used in this study.

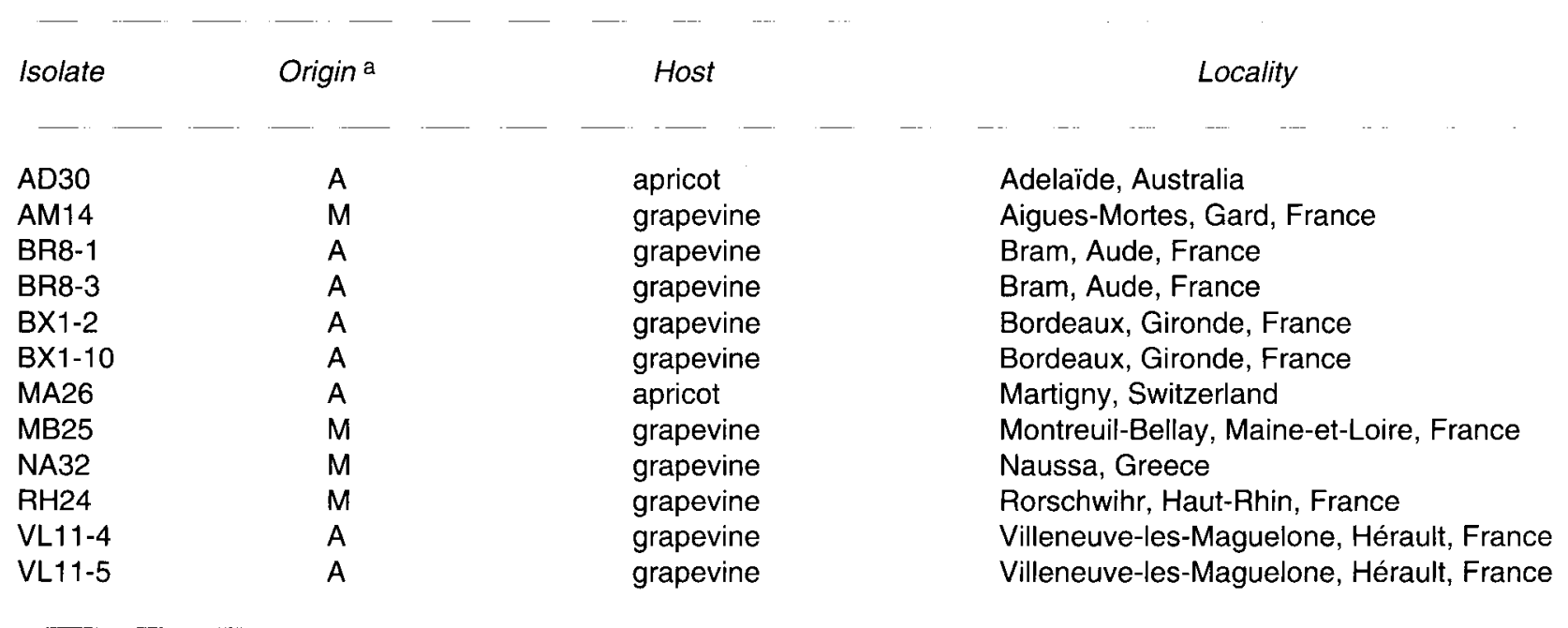

a Isolates originating from single ascospore (A) or from mass mycelium from wood (M).

An isolate experiment and 2 cultivar experiments were performed. The isolate experiment included the isolates listed in table I. Cuttings of cr Cabernet Sauvignon, were inoculated in March 1991. For the cultivar experiments, a total of 15 cultivars (table II) were inoculated with isolate BX1-10 in May 1992 or June 1993. The material used in Experiment 1 came from collection plots (Etablissement National Technique pour l'Amélioration de la Viticulture, Espiguette, Grau-du-Roi) and that used in Experiment 2 from a trial planted at the station.

\section{Incubation in the greenhouse}

Cuttings were inserted just after inoculation into pieces of rock-wool ( $7.5 \times 7.5 \times 6.5 \mathrm{~cm}$, Grodan). The pieces were put into drained plastic containers (20-26 pieces per container) which were placed on benches in a glasshouse. The pieces were continually maintained in a water-saturated condition. To observe the second vegetative growth cycle in the isolate experiment, the plants were transferred 10 weeks after inoculation in a plastic greenhouse into long containers $(20 \mathrm{~m} \times 30 \times$ $30 \mathrm{~cm}$ ) filled with pozzolana. Irrigation was supplied by an oozing sheath and nutrients were provided by a slow release fertilizer (Osmocote). The plants were pruned in December and observed the next spring.

\section{Experimental designs}

Experiments were arranged in complete randomized block designs. The effect of the position of the inocu-

Table II. Identification of the cultivars of grapevine used in the cultivar experiments.

$\begin{array}{llll} & & \\ \text { Cultivar } & \text { Experiment 1 } & \text { Cultivar } \\ \text { Cabernet-Sauvignon } & 62 & \text { Cabernet-Sauvignon } \\ \text { Carignan } & 224 & \text { Carignan } \\ \text { Grenache } & 376 & \text { Sauvignon } \\ \text { Sauvignon } & 478 & \text { Ugni Blanc } \\ \text { Ugni Blanc } & 76 & \text { Alicante Bouschet } \\ \text { Chardonnay } & 174 & \text { Aramon } \\ \text { Gamay } & 519 & \text { Chasselas } \\ \text { Merlot } & 380 & \text { Portugais bleu } \\ \text { Semillon } & 776 & \text { Syrah }\end{array}$

* For the majority of the cultivars, the clone used was not registered or its number was unknown. 
lum was studied with 5 replicates of 8 cuttings per treatment and 4 cuttings per rock-wool piece. The isolate experiment was performed with 10 replicates of 4 cuttings per treatment and 2 cuttings per rock-wool piece. A control was included as a treatment. In the cultivar experiments, each replicate consisted of 8 cuttings with 4 cuttings per rock-wool piece. The cultivar Experiment 1 was performed with 5 replicates and the cultivar Experiment 2 was replicated twice with 4 replicates. Eight control cuttings of each cultivar were included in Experiment 1 and in both replicates of Experiment 2.

\section{Isolation from inoculated cuttings}

Sixteen weeks after bud break, 9 plants observed in the second cycle of vegetative growth cycle were sampled for each treatment of the isolate experiment. At this stage, control plants had 15-20 leaves. At least 4 healthy plants were taken for the more aggressive isolates (table III). The part of the cutting between the inoculation point and the upper node was selected. After removal of the bark, cuttings were surface disinfected as described for wood chips. Three thin chips were cut from cross-sections made with a scalpel at 5 and $20 \mathrm{~mm}$ from the inoculation point. The chips were placed onto plates countaining a semi-selective PDA medium countaining $500 \mathrm{mg} . \mathrm{I}^{-1}$ of chloromycetin (Ferreira et al, 1989) and $5 \mathrm{mg} . \mathrm{l}^{-1}$ of Captan (Carter, 1991). After incubation for 1 week at $25^{\circ} \mathrm{C}$, the plates were examined for the presence of the mycelium of $E$ lata. The reisolated cultures of isolates AD30, AM14, MA 26, VL11-5, BR8-1 and BX1-10 were propagated and inoculated to cuttings of $\mathrm{cv}$ Cabernet Sauvignon in a randomized complete block design with 4 replicates of 8 cuttings.

\section{RESULTS}

\section{Description of symptoms}

Dwarfed and necrotic leaves appeared during the development of the shoots. It was possible to observe the characteristic symptoms of the disease as soon as 3-4 weeks after the inoculation when the shoots were at the $F$ stage. The symptom severity varied within the same treatment (fig 1). Some shoots rapidly showed smaller, chlorosed and necreotic leaves and they generally died (fig 1-A and 1-B). For other shoots, the necrosis appeared firstly on leaves of almost normal size and the severity gradually increased on new leaves; these shoots sometimes stayed alive (fig 1-C). In other cases, a few leaves were necrosed and the leaves which appeared were normal, of reduced size (fig 1-D) or chlorosed. In addition, the cuttings showed other abnormalities: 1) a shoot that died rapidly without producing necrotic leaves; or 2) a shoot with a necrosed tip after emission of a few normal leaves. These abnormalities appeared with a higher incidence for the cuttings inoculated with E lata than for the control cuttings. Therefore, the number of cuttings with these abnormalities was added to the

Table III. Occurrence of $E$ lata at the distance of the inoculation site in cuttings of grapevine (Cabernet-Sauvignon, clone 191) inoculated in the isolate experiment and sampled during the second vegetative growth cycle.

Isolate

\begin{tabular}{|c|c|}
\hline & No tested \\
\hline Control & 9 \\
\hline AD30 & 9 \\
\hline AM14 & 9 \\
\hline MA26 & 9 \\
\hline BR8-1 & 4 \\
\hline BR8-3 & 4 \\
\hline$B \times 1-2$ & 4 \\
\hline$B \times 1-10$ & 8 \\
\hline MB25 & 7 \\
\hline NA32 & 5 \\
\hline $\mathrm{RH} 24$ & 4 \\
\hline VL11-4 & 8 \\
\hline VL11-5 & 8 \\
\hline
\end{tabular}

Samples from normal plants

No positive

9
9
9
6
3
4
4
8
7
4
4
8
7

Samples from plants with foliar symptons

No tested No observed No positive

s.




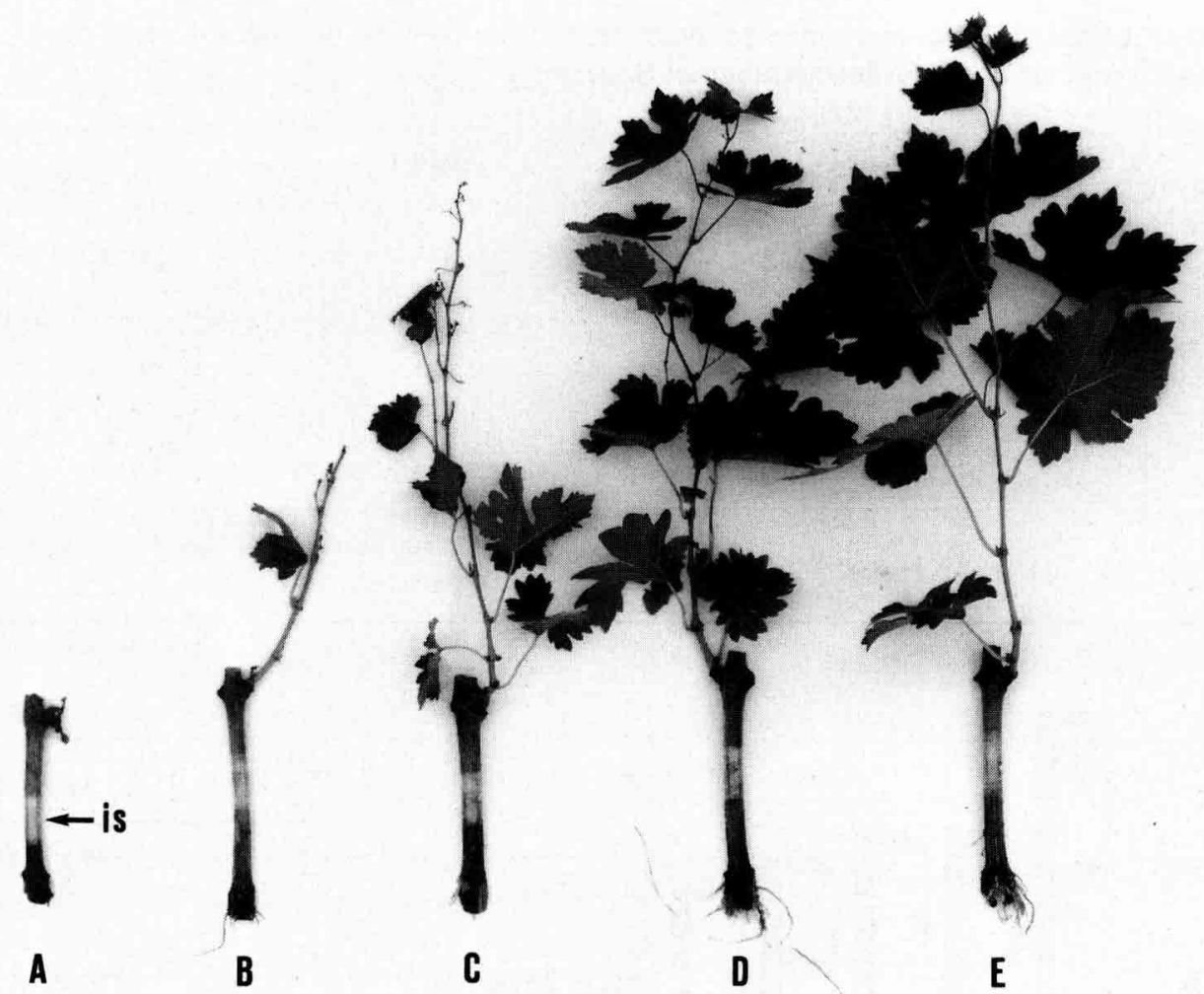

Fig 1. Different types of symptom expression during the first vegetative cycle of cuttings of grapevine cv Cabernet-Sauvignon 8 weeks after the inoculation with $E$ lata: A) and B) smaller and necrotic leaves rapidly appearing on a shoot that generally died; C) symptoms apperaring later on a shoot that stayed alive; D) only a few necrotic leaves and some reduction in leaf size; E) control with normal growth (is: inoculation site).

number of cuttings with foliar symptoms for the analysis of data.

\section{Effect of position of the inoculum site}

The number of abnormal cuttings was recorded 5, 7 and 10 weeks after the inoculation. The effect of the inoculum position was marked 5 weeks after inoculation. The percentage of affected cuttings was indeed considerably larger when the inoculum was positioned under the bud than on the opposite side (52.5 vs $10.0 \%$ ). However, no difference between the treatments was noticed 7 weeks after inoculation. At that time, the percentage rose $70 \%$ and was found unchanged 3 weeks later.

\section{Comparison of isolates}

For the isolate experiment, the number of cuttings showing foliar symptoms and other abnormalities was recorded 8 weeks after inoculation in the first vegetation growth cycle and 8 weeks after bud break in the second vegetation growth cycle. The plants rated with symptoms or other abnormalities in the second year were those rated as healthy in the first year. The analysis of the percentage of total abnormal plants after the first and second years indicated a highly significant effect of the treatment (table IV, fig 2). Isolates VL11-5, AM14, AD30, and MA26 did not differ significantly from the control. Isolates AD30 and MA26 did not induce foliar symptoms and isolates VL11-5 and AM14 induced doubtful foliar symptoms in only a very small number of plants. For the other 8 isolates, the total percentage of abnormal plants varied from 37 to 72 but only the difference between isolates BR8-1 and VL11-4 was significant. Some differences were noted among the aggressive isolates. For instance, disease expression mainly occurred in the first year for isolate BX1-10 whereas only $50 \%$ of the total of affected plants were observed during the first year with isolate BX1-2 (fig 2). Several plants with symptoms in the first year did not show symptoms in the second year, especially for the less aggressive isolates VL11-4, VL11-5 and AM14. The whole experiment was not replicated. However, the differences between isolates were confirmed in further experiments. Notably, the 
Table IV. Effect of isolate of $E$ lata and mean squares (MS) for percentage of total abnormal plants after 2 years of growth of inoculated cuttings of grapevine cv Cabernet-Sauvignon.

\begin{tabular}{|c|c|c|c|c|c|}
\hline \multirow[t]{2}{*}{ Source of variation } & \multirow[t]{2}{*}{$\mathrm{df}$} & \multicolumn{2}{|c|}{ Year 1} & \multicolumn{2}{|c|}{ Year $1+$ year 2} \\
\hline & & MS & $F$ & MS & $\mathrm{F}$ \\
\hline Replication & 9 & 1806.09 & $4.44^{\star}$ & 1325.32 & $2.67^{\star}$ \\
\hline Isolate & 12 & 4552.08 & $11.19^{\star}$ & 6759.81 & $13.64^{*}$ \\
\hline Error & 108 & 406.78 & & 495.46 & \\
\hline
\end{tabular}

${ }^{*} F$ test significant at $P=0.01\left(F_{9,100}=2.59 ; F_{12,100}=2.36\right)$

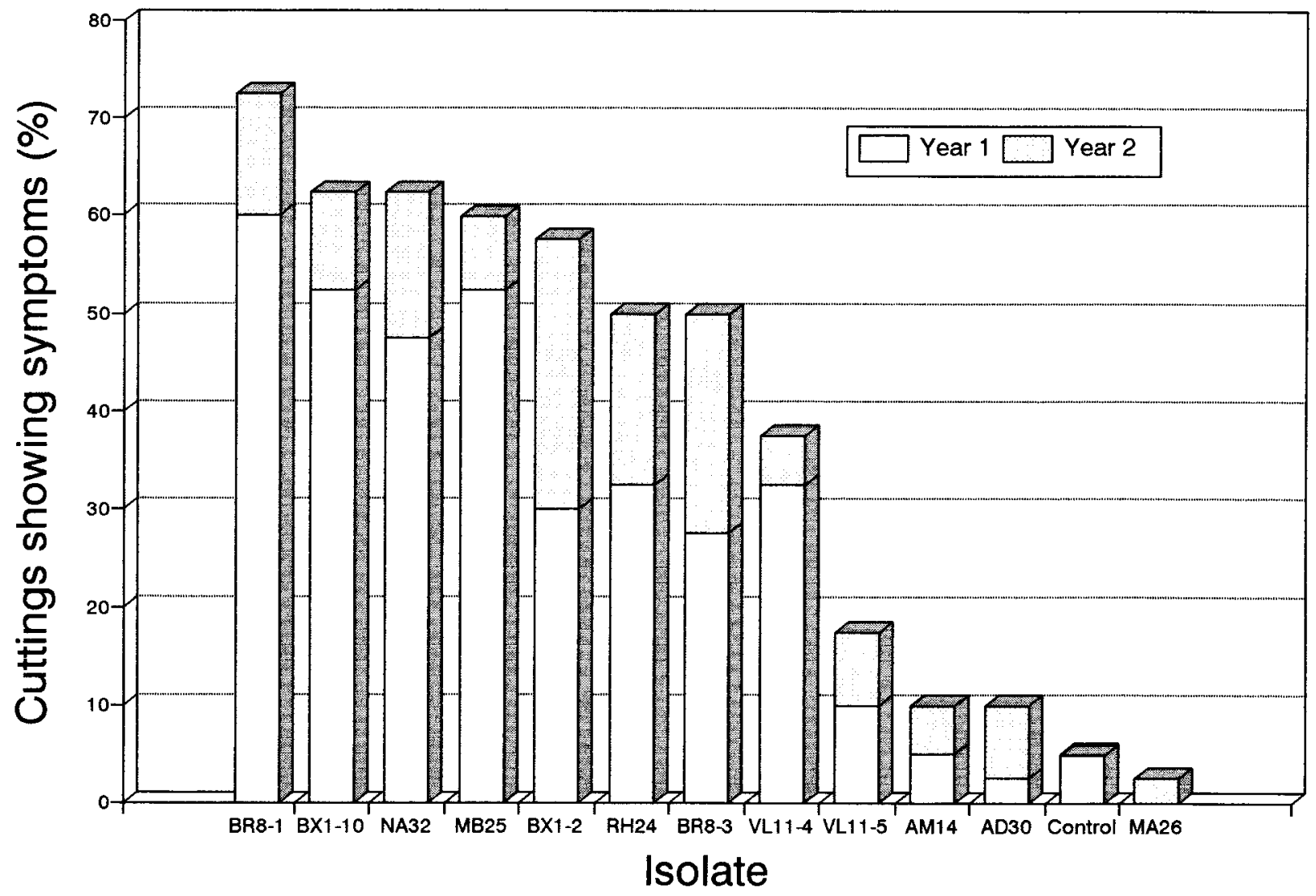

Fig 2. Effect of the isolate of $E$ lata on numbers of cuttings of grapevine cv Cabernet-Sauvignon showing foliar symptoms of Eutypa dieback and other abnormalities during 2 consecutive years of growth in the greenhouse. Dunnet at $p=0.05: 27.73$ for year 1 and 25.12 for final percentage.

isolates AM14 and VL11-5 never induced foliar symptoms again.

Despite the semi-selective medium we used for reisolation, some chips yielded other fungi, thus reducing the number of available observations (table IV). When the fungus was reisolated from a cutting, the samples taken at 5 and 20 $\mathrm{mm}$ were generally positive. Therefore, the distance at which the fungus occurred was no longer considered. For all isolates, reisolation was positive in some of the cuttings that had a normal growth. At least $35 \%$ of these cuttings were infected and the percentage was similar for non-aggressive isolates (AD30, MA26, AM14, and VL11-5) and aggressive isolates (others isolates). The morphology of the cultures closely conformed to the original characteristics of the isolates. In addition, inoculation of cuttings with the cultures of isolates AD30, MA26, AM14 and VL11-5 did not induce symptoms contrary to cultures of isolates $B \times 1-10$ and BR8-1 chosen as controls (data not shown). The number of available cuttings showing typical symptoms was low in the second vegetative growth cycle due to high 
mortality (BX1-10) or the low incidence of symptoms (VL11-4, VL11-5). All the isolates tested were again reisolated but the percentage of positive cuttings $(64 \%)$ was higher than for normal plants.

\section{Comparison of cultivars}

The number of cuttings showing foliar symptoms and others abnormalities were recorded 5 and 10 weeks after inoculation in cultivar experiments. No difference was found between the 2 replicates of Experiment 2 and the pooled data was analyzed. All the cultivars inoculated exhibited foliar symptoms of the disease and the other abnormalities. Control cuttings of cvs Semillon and Tempranillo (Experiment 1) and cvs Grenache and Syrah (Experiment 2) had a large percentage of plants with abnormalities. The results for these cultivars were therefore not included in the statistical analyses. In both experiments, the effect of cultivar was highly significant (table V). Some of the shoots showing necrotic leaves 5 weeks after inoculation showed normal growth 10 weeks after inoculation and this phenomenon explained the decrease in some percentages. The differences between cultivars were less acute 10 weeks after inoculation (table VI) indicating that the effects of the fungus appeared faster for some cultivars than for others.

\section{DISCUSSION}

Inoculated cuttings produced foliar symptoms during the first vegetative growth cycle. The smaller and necrotic leaves were similar to that observed in shoots of infected vines in the vineyard. Moreover, the necrosis of lamina was identical to that reproduced on leaves by the fungal culture filtrate or by eutypine. Therefore, the rapid appearance of symptoms seems to be a consequence of the transport of toxic products from the inoculation site to the growing shoot. This conclusion is sustained by the effect of the position of the inoculum site. The symptoms appeared faster when the vessels in direct connection with the sprouting shoot were first colonized by the fungus. The late appearance of symptoms during the second vegetative growth in previous work (Petzolt et al, 1981; Mur, 1988) was probably due to differences in the method or the isolate characteristics.

It was indeed shown that the incidence of the symptoms depends markedly on the isolate of $E$ lata. Isolates may differ in their ability to produce toxic compounds and colonize the wood. These 2 components of pathogenesis are probably related, since toxins may help colonization and since a higher fungal biomass can synthesize larger quantities of toxins. Reisolation indicated that cuttings with a normal growth were colonized by $E$ lata. However, reisolation of the fungus was more frequent from plants with symptoms, ie

Table V. Grapevine cultivar effect and mean squares (MS) for percentage of abnormal plants after inoculation with $E$ lata isolate BX1-10 in cultivar Experiment 1.

\begin{tabular}{|c|c|c|c|c|c|}
\hline \multirow[t]{3}{*}{ Source of variation } & \multirow[t]{3}{*}{$d f$} & \multicolumn{4}{|c|}{ Weeks after inoculation } \\
\hline & & \multicolumn{2}{|c|}{5} & \multicolumn{2}{|c|}{10} \\
\hline & & MS & $\mathrm{F}$ & MS & $\mathrm{F}$ \\
\hline \multicolumn{6}{|l|}{ Experiment 1} \\
\hline Replication & 4 & 376.95 & 1.14 & 757.81 & 2.51 \\
\hline Cultivar & 7 & 3651.79 & $11.06^{\star}$ & 1345.98 & $4.45^{\star}$ \\
\hline Error & 28 & 330.08 & & 302.46 & \\
\hline \multicolumn{6}{|l|}{ Experiment 2} \\
\hline Replication & 3 & 218.92 & 1.70 & 757.81 & 2.51 \\
\hline Cultivar & 7 & 892.48 & $6.92^{\star}$ & 348.10 & $4.24^{*}$ \\
\hline Error & 21 & 128.99 & & 82.18 & \\
\hline
\end{tabular}

\footnotetext{
* F test significant at $P=0.01\left(\mathrm{~F}_{7,28}=3.36, \mathrm{~F}_{7,21}=3.65\right)$.
} 
Table VI. Effect of grapevine cultivar on percentage of plants showing foliar symptoms and abnormalities after inoculation with $E$ lata isolate BX1-10.

\section{Experiment 1}

Symptoms (\%)
Cultivar 5 weeks 10 weeks

$\begin{array}{lll}\text { Cabernet-Sauvignon } & 95.0 & 87.5 \\ \text { Ugni blanc } & 77.5 & 70.0 \\ \text { Gamay } & 80.0 & 80.0 \\ \text { Merlot } & 57.5 & 70.0 \\ \text { Sauvignon } & 55.0 & 80.0 \\ \text { Carignan } & 62.5 & 70.0 \\ \text { Chardonnay } & 30.0 & 40.0 \\ \text { Grenache } & 12.5 & 47.5 \\ & & \\ \text { Dunnet at } P=0.05 & 31.9 & 30.5\end{array}$

plants which probably contained higher quantities of mycelium. A variation in the aggressiveness among $E$ lata isolates was already observed when apricot was inoculated (Ramos et al, 1975; Carter et al, 1985; Rumbos, 1987) or in biossays for grapevine (Mauro et al, 1988).

The isolates AD30 and MA26 did not induce necrosis of grapevine leaves in our tests but were able to colonize the wood. As these isolates originated from apricot; they may represent a different pathotype with less aggressiveness towards the grapevine. Another explanation could be a loss of characteristics, ie toxin production, since isolates AD30 and AM26 had been stored for 15-20 years on malt agar medium at $5^{\circ} \mathrm{C}$ and subcultured every $2-3$ years (Bolay, personnal communication). However, others isolates like AM14 and VL11-5, isolated recently from grapevine, also appeared to be weakly aggressive. Variation in the characteristics of single ascospore isolates can be explained by the variability arising from sexual recombination. It is more surprising to isolate weakly aggressive isolated from plants showing symptoms of Eutypa dieback. However, as pointed out by Carter et al (1985), diseased wood may yield a mixture of mycelia differing in their aggressiveness.

The cultivars had different responses in the test indicating that cultivars differ in their susceptibility to fungal toxins and to fungal invasion. Variations in cultivar susceptibility are also observed in vineyard and Dubos (1987) proposed 4 categories of susceptibility for the cultivars grown in France. These field observations
Experiment 2

Cultivar

Symptoms (\%)

5 weeks $\quad 10$ weeks

$\begin{array}{lll}\text { Cabernet-Sauvignon } & 93.8 & 90.6 \\ \text { Ugni Blanc } & 87.5 & 86.0 \\ \text { Chasselas } & 84.4 & 84.4 \\ \text { Portugais } & 82.8 & 89.1 \\ \text { Alicante } & 70.4 & 78.2 \\ \text { Carignan } & 57.9 & 75.0 \\ \text { Aramon } & 59.4 & 68.8 \\ \text { Sauvignon } & 56.3 & 65.7 \\ & & \\ \text { Dunnet at } P=0.05 & 23.0 & 18.3\end{array}$

are clearly in accordance with the responses in the test for several cultivars. The high susceptibility of cvs like Cabernet-Sauvignon, Ugni blanc and Chasselas was confirmed. In the Gironde, cv Cabernet-Sauvignon is considerably more affected than cv Merlot and the inoculation of cuttings caused a faster appearance of abnormal plants for cv Cabernet-Sauvignon than for cv Merlot (table VI). The cvs Carignan and Aramon are considered as tolerant in the LanguedocRoussillon region and were effectively less affected than susceptible cultivars in the test. However, very susceptible cvs like Sauvignon, Grenache and Chardonnay were not rated in accordance to vineyard observations. Problems may result from differences in growth of the selfrooted cuttings. For instance, the response from several cultivars was not analyzed because their cuttings were unable to fully develop in the conditions of growth adopted, probably because they developed roots insufficiently or too late. Effects of similar quantities of toxic products may vary according to a dilution effect due to the size or the growth of the shoots. This was illustrated by the variation in symptom severity observed in the same cultivar and by the recovery of some plants that initially presented symptoms and then underwent normal growth. It is probably difficult to find a complete correlation between observations in the vineyard and data obtained with a rapid method of assessment. This is particularly true for a disease like Eutypa dieback, which is a long-term disease influenced by diverse factors in the vineyard. 
In conclusion, data presented here show that inoculation of cuttings can be used to study the pathogen variability and to rate the cultivar susceptibility. The method may also be a useful tool to study the disease. The colonization of the wood can be followed in relation with the appearance of foliar symptoms for a range of isolates differing in their aggressiveness and a range of cultivars differing in their response. The detection of eutypine, fungal enzymes and host phenolic compounds into the cuttings could then provide information on the respective importance of several pathogenic components and their resistance mechanisms.

\section{ACKNOWLEDGMENTS}

We thank J Balthazard E Paillassa, M Penavayre and C Rumbos for infected vines, A Bolay for isolates AD30 and MA26 and S Grenan for plant material used in this study. We also thank MV Carter for critically reviewing the manuscript. This work was financed in part by a grant from the Office National Interprofessionnel des Vins.

\section{REFERENCES}

Belarbi B (1983) Contribution à l'étude de la résistance des Vitaçées à l'Eutypiose (Eutypa armeniacae Hanfs \& Carter) et à l'Esca (Stereum hirsutum Wild Persoon), Thesis, Ecole Nat Sup Agron, Montpellier, France, $68 \mathrm{pp}$

Bolay A, Moller WJ (1977) Eutypa armeniacae Hansf and Carter, agent d'un grave dépérissement de vignes en production. Rev Suisse Vitic Arboric Hortic 9, 241-251

Carter MV (1991) The status of Eutypa lata as a pathogen. Phytopathol Pap 32, Int Mycol Inst Cab Int, Oxon, UK

Carter MV, Bolay A, English H, Rumbos I (1985) Variation in the pathogenicity of Eutypa lata $(=E$ armeniacae). Aust J Bot 33, 361-366
Dubos B (1987) Mise au point sur les maladies de dépérissement dans le vignoble français. Prog Agric Vitic 104, 135-140

Elghazali B, Gas G, Fallot J (1992) Biodégradation des lignocelluloses de vigne (Vitis vinifera cv Cabernet Sauvignon) par Eutypa lata (Pers Fr) Tul. Vitis 31, 95-103

Fallot J, Tey-Rulh P, Coutouly P et al (1990) Culture in vitro, étude de l'eutypiose et stratégie de création de somaclones de vigne tolérants. In: Cinquantenaire de la Culture in vitro (C Doré, ed), colloq INRA, France, 51, 151-159

Ferreira JHS, Matthee FN, Thomas AC (1989) Fungi associated with dieback and pruning wounds of grapevines in South Africa. S Afr J Enol Vitic 10, 6266

Mauro MC, Vaillant V, Tey-Rulh P, Mathieu Y, Fallot J (1988) In vitro study of the relationships between Vitis vinifera and Eutypa lata (Pers:Fr) Tul I. Demonstration of toxic compounds secreted by the fungus. Amer J Enol Vitic 39, 200-204

Moller WJ, Kasimatis AN (1981) Further evidence that Eutypa armeniacae - not Phomopsis viticola - incites dead arm symptoms on grape. Plant Dis 65, 429-431

Mur G (1988) Les maladies du bois de la vigne. Prog Agric Vitic 105, 575-577

Petzold CH, Moller WJ, Sall MA (1981) Eutypa dieback of grapevine: seasonal differences in infection and duration of susceptibility of pruning wounds. Phytopathology 71, 540-543

Ramos DE, Moller WJ, English H (1975) Susceptibility of apricot tree pruning to the infection by Eutypa armeniacae. Phytopathology 95, 1359-1364

Renaud JM (1985) Isolement et identification de métabolites secondaires et phytotoxiques d'Eutypa armeniacae. Thesis. Université de Neuchatel, Switzerland, $148 \mathrm{pp}$

Rumbos IC (1987) Effects of pathotypes and time of year on the susceptibility of apricot to the infection by Eutypa lata. Phytopathol Mediterr 26, 85-90

Soulié O, Roustan JP, Fallot J (1993) Early in vitro selection of eutypine-tolerant plantlets. Application to screening of Vitis vinifera cv Ugni blanc somaclones. Vitis 32, 243-244

Tey-Rulh P, Philippe I, Renaud JM et al (1991) Eutypine, a phytotoxin produced by Eutypa lata the causal agent of dying-arm disease of grapevine. Phytochemistry 30, 471-473 